\title{
Erythrapheresis in patients with polycythaemia secondary to hypoxic lung disease
}

\author{
J A WEDZICHA, R M RUDD, M C P APPS, F E COTTER, A C NEWLAND, D W EMPEY
}

\begin{abstract}
Erythrapheresis was performed in 10 patients with polycythaemia secondary to hypoxic lung disease (mean $\left.\mathrm{PaO}_{2}, 6 \cdot 8 \mathrm{kPa}(51 \mathrm{~mm} \mathrm{Hg})\right)$. The mean packed cell volume decreased from 0.64 to 0.48 in men and from 0.56 to 0.42 in women, with significant decreases in blood viscosity at both high and low shear rates $(p<0.001)$. Patients showed significant improvement in six-minute walking distances $(p<0.001)$ and in tests of mental alertness $(p<0.01)$ compared to control subjects. Visual analogue scales confirmed symptomatic improvement after erythrapheresis.

Erythrapheresis significantly improved symptoms, mental function, and work performance in patients with polycythaemia secondary to hypoxic lung disease. The procedure was well tolerated by all patients and no complications occurred.
\end{abstract}

\section{Introduction}

Polycythaemia may develop in patients with chronic hypoxic lung disease as a compensation for reduced arterial oxygen saturation. Although this increases the oxygen carrying capacity of the blood, the rise in packed cell volume causes an exponential rise in blood viscosity. ${ }^{1}$ This may eventually reduce tissue blood flow and thus impair oxygen delivery.

Studies in dogs have shown that as the packed cell volume is raised above 0.55 the consequent increase in blood viscosity is

London Chest Hospital, London E2 9JX

J A WEDZICHA, MRCP, registrar

R M RUDD, MRCP, senior registrar

M C P APPS, MRCP, honorary senior registrar

D W EMPEY, MRCP, consultant physician

Department of Haematology, London Hospital, Whitechapel, London E1 1BB

F E COTTER, MRCP, registrar

A C NEWLAND, MRCPATH, senior lecturer associated with a fall in cardiac output, which overrides the gain in oxygen carrying capacity of the blood, thereby causing a decrease in systemic oxygen transport. ${ }^{2}$ In patients with polycythaemia secondary to hypoxic lung disease therapeutic reduction of packed cell volume might, therefore, produce a net improvement in oxygen delivery. Earlier studies have shown that cerebral blood flow may improve ${ }^{3}{ }^{4}$ and work capacity increase, ${ }^{5}$ but haemodynamic improvement is not always shown. ${ }^{8}$

Assessment of the value of reducing packed cell volume has been complicated by the other effects of the methods adopted. Venesection has been widely advocated ${ }^{7}$ but is associated with an immediate fall in cardiac output and subsequent thrombocytosis, occasionally with fatal consequences. ${ }^{8}$ Reductions in packed cell volume may be fairly small on each occasion, and in a study of patients with polycythaemia secondary to hypoxic lung disease it took an average of seven weeks to reduce the packed cell volume to within normal limits." Isovolaemic exchange transfusion with the plasma expander dextran 40 allows more rapid lowering of packed cell volume, but it must be infused over about 12 hours and causes fluid shifts between vascular compartments. ${ }^{9}$ Continuous oxygen treatment reduces packed cell volume but only when used for six weeks. ${ }^{10}$ Antimalarial drugs have been used but may cause marrow suppression."1

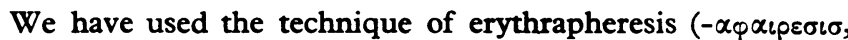
$-\operatorname{aph}(\mathrm{a})$ eresis $=\mathrm{a}$ taking away $)^{12}$ to reduce the packed cell volume in a rapid and controlled manner to within normal limits, without associated changes in blood volume, in patients with chronic hypoxic lung disease.

\section{Patients and methods}

We studied 10 patients (four men, six women) with polycythaemia secondary to chronic obstructive bronchitis with arterial hypoxaemia: packed cell volume was above 0.54 for men and above 0.47 for women (upper limits of normal for our laboratory). There was no other cause for polycythaemia, and none of the patients were smoking at the time of the study. The patients' medical condition was stable; heart failure, where present, was controlled and diuretic dosages had not been recently altered. Table I gives details of the patients. All patients gave informed consent for the procedures, and the study was approved by the hospital ethics committee. 
TABLE I-Clinical details of patients studied

\begin{tabular}{cccccc}
\hline $\begin{array}{c}\text { Case } \\
\text { No }\end{array}$ & Age & Sex & $\begin{array}{c}\mathrm{PaO}_{2} \\
(\mathrm{kPa})\end{array}$ & $\begin{array}{c}\text { Haemoglobin } \\
(\mathrm{g} / \mathrm{dl})\end{array}$ & $\begin{array}{c}\text { Packed cell } \\
\text { volume* }\end{array}$ \\
\hline 1 & 62 & $\mathrm{M}$ & 6.7 & 21.6 & 0.71 \\
2 & 59 & $\mathrm{M}$ & 6.9 & 19.7 & 0.64 \\
3 & 58 & $\mathrm{~F}$ & 6.3 & 20.2 & 0.64 \\
4 & 75 & $\mathrm{M}$ & 6.3 & 18.5 & 0.63 \\
5 & 51 & $\mathrm{~F}$ & 5.6 & 16.6 & 0.61 \\
6 & 67 & $\mathrm{~F}$ & 6.5 & 17.8 & 0.59 \\
7 & 48 & $\mathrm{M}$ & 8.5 & 18.0 & 0.56 \\
8 & 59 & $\mathrm{~F}$ & 8.5 & 17.0 & 0.53 \\
9 & 59 & $\mathrm{~F}$ & 5.9 & 16.7 & 0.52 \\
10 & 51 & $\mathrm{~F}$ & 6.5 & 16.7 & 0.49 \\
\hline Mean \pm SD & $59 \pm 8$ & & $6.8 \pm 1.0$ & $18.3 \pm 1.7$ & $0.59 \pm 0.07$ \\
\hline
\end{tabular}

* Mean packed cell volume for men, $0.64 \pm 0.06$; women, $0.56 \pm 0.06$.

Conversion: SI to traditional units-1 kPa $\approx 7.5 \mathrm{~mm} \mathrm{Hg}$.

Isovolaemic haemodilution was carried out using the Haemonetics V50 blood processor with a component collection set (No 603) modified by Haemonetics. Venous access was obtained using a single 14G butterfly needle in a peripheral vein. Patients were given 2500 IU heparin before the procedure and the blood was also heparinised continuously as it left the patient. In the bowl of the blood processor the blood was separated by centrifugal force into red cells and plasma: about $250 \mathrm{ml}$ of packed cells were obtained with each cycle (packed cell volume $=0.75$ ). The platelet rich plasma was returned to the patient and the balance made up with human plasma protein fraction. The cycle was then repeated intermittently until a volume up to 1000 $\mathrm{ml}$ of packed cells had been collected. The whole procedure lasted
We administered tests of mental alertness based on those used by Willison et al, together with a short term memory test. ${ }^{17}$ Each test was performed twice before and twice after erythrapheresis. The tests were: (a) letter cancellation, (b) digit copying, (c) counting backwards from 30 , and $(d)$ word repetition (for short term memory). The time to completion of each test (in seconds) was noted as the score except in the word repetition test where the number of words was recorded. The same tests were performed twice on two separate days in a group of 10 control subjects with hypoxic lung disease but without polycythaemia. There were no significant educational or occupational differences between the two groups.

The patients were asked to complete a standard $10 \mathrm{~cm}$ visual analogue scale with respect to the following symptoms: shortness of breath, headache, tiredness, sadness, mood, sleepiness, and how terrible they felt before and after erythrapheresis.

Statistical analysis-The Student's $t$ test (two tailed) paired or unpaired as appropriate was used for comparison of means for parametric data. The Mann-Whitney $U$ test (two tailed) and the Wilcoxon matched pairs signed ranks test (two tailed) were used for group comparison of walking distances, psychometric tests, and visual analogue scores. Mean results for the groups are given $\perp$ SD.

\section{Results}

Erythrapheresis was well tolerated by all patients, and there were no adverse reactions to the procedure. Table II shows the values of the haemoglobin and packed cell volume for each patient before and after erythrapheresis and the volume of red cells removed. The mean changes in packed cell volume were from $0.64 \pm 0.06$ (mean $\pm S D$ ) to

TABLE II-Haematological measurements before and after erythrapheresis

\begin{tabular}{|c|c|c|c|c|c|c|c|}
\hline \multirow{3}{*}{$\begin{array}{l}\text { Case } \\
\text { No }\end{array}$} & & & \multicolumn{4}{|c|}{ Viscosity (mPa s)* } & \multirow{3}{*}{$\begin{array}{l}\text { Volume of } \\
\text { red cells } \\
\text { removed } \\
(\mathrm{ml})\end{array}$} \\
\hline & \multicolumn{2}{|c|}{ Packed cell volume } & \multicolumn{2}{|c|}{$23 / \mathrm{s}$} & \multicolumn{2}{|c|}{$230 / \mathrm{s}$} & \\
\hline & Before & After & Before & After & Before & After & \\
\hline $\begin{array}{r}1 \\
2 \\
3 \\
4 \\
5 \\
6 \\
7 \\
8 \\
9 \\
10\end{array}$ & $\begin{array}{l}0.71 \\
0.64 \\
0.64 \\
0.63 \\
0.61 \\
0.59 \\
0.56 \\
0.53 \\
0.52 \\
0.49\end{array}$ & $\begin{array}{l}0.54 \\
0.51 \\
0.46 \\
0.45 \\
0.42 \\
0.42 \\
0.41 \\
0.44 \\
0.49 \\
0.30\end{array}$ & $\begin{array}{r}17.5 \\
13.3 \\
12.8 \\
12.1 \\
9.9 \\
9.2 \\
9.6 \\
11.1 \\
9.7 \\
7.3\end{array}$ & $\begin{array}{l}7.2 \\
7.5 \\
4.3 \\
7.2 \\
7.3 \\
5.3 \\
6.0 \\
7.4 \\
6.6 \\
3.3\end{array}$ & $\begin{array}{r}10.0 \\
7.0 \\
7.2 \\
7.0 \\
5.3 \\
5.7 \\
5.8 \\
5.6 \\
5.5 \\
4.3\end{array}$ & $\begin{array}{l}4 \cdot 8 \\
4 \cdot 4 \\
2 \cdot 7 \\
4 \cdot 5 \\
3 \cdot 8 \\
3 \cdot 2 \\
3 \cdot 7 \\
4 \cdot 4 \\
4 \cdot 3 \\
2 \cdot 2\end{array}$ & $\begin{array}{c}2000 \dagger \\
800 \\
1335 \dagger \\
750 \\
500 \\
400 \\
800 \\
400 \\
600 \\
600\end{array}$ \\
\hline Mean \pm SD & $0.59 \pm 0.07$ & $0.44 \pm 0.06$ & $11 \cdot 3 \pm 2 \cdot 9$ & $6 \cdot 2 \pm 1.5$ & $6 \cdot 3 \pm 1 \cdot 6$ & $3.8 \pm 0.9$ & \\
\hline
\end{tabular}

* Normal range for shear rate $23 / \mathrm{s}, 4 \cdot 0-6.0 \mathrm{mPa} \mathrm{s}$; for $230 / \mathrm{s}, 3.4-3.8 \mathrm{mPa}$ s.

+Cases 1 and 3 required erythrapheresis on two occasions.
Conversion: SI to traditional units-Viscosity: 1 millipascal second $(\mathrm{mPa} s) \approx 1$ centipoise $(\mathrm{cP})$.

about 90 minutes on an outpatient basis (full technical details may be obtained from ACN).

Patients were assessed 24 hours before and 24 hours after erythrapheresis. Venous blood was taken without stasis and anticoagulated using potassium edetic acid. The haemoglobin and haematocrit concentrations and red cell count were determined using a Coulter Counter model 5. The microhaematocrit was determined using ${ }^{125} \mathrm{I}-$ labelled albumin as a plasma label to measure trapped plasma in a packed cell column after 15 minutes' centrifugation. The measured haematocrit was corrected by the observed trapped plasma. ${ }^{13}$ Viscosity of whole blood was measured at $37^{\circ} \mathrm{C}$ using a cone-plate viscometer (Wells Brookfield model LVT) at shear rates of 230/s and 23/s. Measurements were made within three hours of erythrapheresis. Carboxyhaemoglobin was measured spectrophotometrically and calculated against standard solutions. ${ }^{14}$

Arterialised capillary blood was taken from the ear lobe and analysed immediately for gas tensions on a Radiometer ABL 1 analyser. The forced expiratory volume in $1 \mathrm{~s}$ and the forced vital capacity were measured with a Morgan dry spirometer; gas transfer for carbon monoxide was measured by the single breath technique using a P K Morgan Transfertest machine. The distance walked on the level in six minutes was used as an estimate of exercise tolerance. ${ }^{15} 16$ After an initial practice walk the distance achieved was measured before and after erythrapheresis. Ten control subjects with chronic bronchitis undertook a similar series of walks and were matched for the initial walking distances.
$0.48 \pm 0.06$ for men and $0.56 \pm 0.06$ to $0.41 \pm 0.07$ for women. There were significant reductions in blood viscosity after the procedure when measured at both high and low shear rates. Thrombocytosis was not observed after the procedure. After erythrapheresis there were no significant changes in spirometric volumes or blood gases, but there were significant decreases in both carbon monoxide gas transfer, $\left(T_{L} C O\right)$ and the gas transfer coefficient $(\mathrm{KcO})$. When corrected to a haemoglobin concentration of $14.6 \mathrm{~g} / \mathrm{dl}$, however, there was no significant change in $\mathrm{T}_{\mathrm{L}} \mathrm{CO}$ or $\mathrm{KcO},{ }^{18}{ }^{19}$ (table III). Carboxyhaemoglobin concentrations were below $1 \%$ in all subjects.

Every patient walked further in six minutes after erythrapheresis. The mean distance walked after erythrapheresis was $364 \mathrm{~m}$, compared to the significantly shorter distance of $303 \mathrm{~m}$ before treatment ( $<<0.001$; table III). There was no significant increase in the distance walked by control subjects between the first and second occasions, and the distance walked by the control subjects on the second occasion was significantly less than that of the patients after erythrapheresis $(\mathrm{p}<0.001$; table III).

Table IV shows the results of the psychometric tests. After erythrapheresis the patients with polycythaemia showed a significant improvement in scores on all three tests of mental alertness but no change in the test of short term memory (word repetition). The control subjects (mean $\mathrm{Po}_{2}, 7 \cdot 7 \pm 1.0 \mathrm{kPa}(57 \cdot 8 \pm 7.5 \mathrm{~mm} \mathrm{Hg})$ ) showed no significant improvement in any test on the second occasion, suggesting that learning did not have an important influence on the results. The increases in scores in all three tests of alertness after erythrapheresis 
TABLE III-Results of pulmonary function and exercise tests

\begin{tabular}{|c|c|c|c|}
\hline & $\begin{array}{l}\text { Before } \\
\text { erythrapheresis }\end{array}$ & $\begin{array}{c}\text { After } \\
\text { erythrapheresis }\end{array}$ & $\underset{\text { Value }}{\mathrm{p}}$ \\
\hline $\begin{array}{l}\mathrm{PaO}_{2}(\mathrm{kPa}) \\
\mathrm{PaCO}_{2}(\mathrm{kPa}) \\
\mathrm{FEV}_{1}(\mathrm{l}) \\
\mathrm{FVC}(\mathrm{l}) \\
\mathrm{T}_{\mathrm{LCO}}(\mathrm{mmol} \mathrm{min} / \mathrm{kPa}) \\
\mathrm{T}_{\mathrm{LCO}}(\mathrm{mmol} \mathrm{min} / \mathrm{kPa})^{*} \\
\mathrm{KCO}(\mathrm{mmol} \mathrm{min} / \mathrm{kPa} /)^{*} \\
\mathrm{KCO}(\mathrm{mmol} \min / \mathrm{kPa} /)^{*}\end{array}$ & 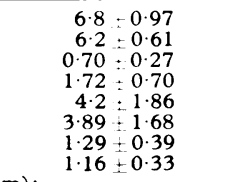 & $\begin{array}{rl}6.5 & 2 \cdot 20 \\
6 \cdot 2 & 1.10 \\
0 \cdot 71 & 0.22 \\
1.64 & 0.61 \\
3.6 & 1.86 \\
3.54 & 1.79 \\
1 \cdot 10 & 0.26 \\
1 \cdot 11 & 0.27\end{array}$ & $\begin{array}{l}\text { NS } \\
\text { NS } \\
\text { NS } \\
\text { NS } \\
\text { p } 0.02 \\
\text { NS } \\
\text { p } 0.025 \\
\text { NS }\end{array}$ \\
\hline $\begin{array}{l}6 \text { minute walking distan } \\
\text { Patients } \\
\text { Controls }\end{array}$ & $\begin{array}{l}\text { m): } \\
303 \text { (range } 77-480 \text { ) } \\
303 \text { (range } 120-470 \text { ) }\end{array}$ & $\begin{array}{l}364 \text { (range } 91-560 \text { ) } \\
304 \text { (range } 120-480 \text { ) }\end{array}$ & $\underset{\text { NS }}{p} 0.001$ \\
\hline
\end{tabular}

* Corrected to haemoglobin concentration $14.6 \mathrm{~g}$ dl.

Conversion: SI to traditional units $-1 \mathrm{kPa}=7.5 \mathrm{~mm} \mathrm{Hg}$.

TABLE IV-Results of psychometric tests in 10 patients with polycythaemia and 10 control subjects

\begin{tabular}{|c|c|c|c|c|c|}
\hline \multirow{3}{*}{ Test } & \multicolumn{4}{|c|}{ Mean scores } & \multirow{3}{*}{$\begin{array}{c}\text { Significance } \\
\text { of differences } \\
\text { between } \\
\text { two scores }\end{array}$} \\
\hline & \multicolumn{2}{|c|}{ Before erythrapheresis } & \multicolumn{2}{|c|}{ After erythrapheresis } & \\
\hline & 1st test & 2nd test & 1st test & 2nd test & \\
\hline $\begin{array}{l}\text { Letter cancellation: } \\
\text { Patients } \\
\text { Controls }\end{array}$ & $\begin{array}{l}50 \\
49\end{array}$ & $\begin{array}{l}50 \\
47\end{array}$ & $\begin{array}{l}42 \\
51\end{array}$ & $\begin{array}{l}40 \\
48\end{array}$ & $\begin{array}{c}\mathrm{p}<0.01 \\
\text { NS }\end{array}$ \\
\hline $\begin{array}{l}\text { Number copying: } \\
\text { Patients } \\
\text { Controls }\end{array}$ & $\begin{array}{l}47 \\
47\end{array}$ & $\begin{array}{l}45 \\
43\end{array}$ & $\begin{array}{l}38 \\
47\end{array}$ & $\begin{array}{l}37 \\
45\end{array}$ & $\begin{array}{c}\mathrm{p}<0.01 \\
\text { NS }\end{array}$ \\
\hline $\begin{array}{l}\text { Counting backwards: } \\
\text { Patients } \\
\text { Controls }\end{array}$ & $\begin{array}{l}32 \\
20\end{array}$ & $\begin{array}{l}31 \\
20\end{array}$ & $\begin{array}{l}23 \\
20\end{array}$ & $\begin{array}{l}22 \\
20\end{array}$ & $\begin{array}{c}\mathrm{p}<0.01 \\
\mathrm{NS}\end{array}$ \\
\hline $\begin{array}{l}\text { Word memory: } \\
\text { Patients } \\
\text { Controls }\end{array}$ & $\begin{array}{l}6 \cdot 6 \\
6 \cdot 2\end{array}$ & $\begin{array}{l}6.4 \\
6.3\end{array}$ & $\begin{array}{l}6 \cdot 3 \\
6 \cdot 3\end{array}$ & $\begin{array}{l}6.0 \\
6.5\end{array}$ & $\begin{array}{l}\text { NS } \\
\text { NS }\end{array}$ \\
\hline
\end{tabular}

were significantly greater than the increases in scores between the first and second occasions in control subjects (test $1, \mathrm{p}<0.001$; test 2 , $\mathrm{p}<0.05$; test $3, \mathrm{p}<0.01$ ).

On the visual analogue scales the patients showed significant improvement after erythrapheresis with respect to the following symptoms: shortness of breath $(p<0.05)$, sadness $(p<0.01)$, mood $(p<0.01)$, and how terrible they felt $(p<0.02)$, but there were no significant differences in tiredness, headache, and sleepiness.

\section{Discussion}

Packed cell volume may be successfully reduced by erythrapheresis in patients with polycythaemia secondary to hypoxic lung disease. There were no complications related to the procedure; it was acceptable to the patients, and all reported symptomatic benefit within 24 hours. Two months after erythrapheresis, the packed cell volumes of all the patients were still within normal limits and symptomatic benefit was maintained.

We chose erythrapheresis for this study because of the rapidity with which packed cell volume can be reduced without the risk of associated changes in blood volume, fluid shifts between vascular compartments, or subsequent thrombocytosis. The procedure can be carried out in 90 minutes in outpatients. Reduction of packed cell volume by other techniques has been shown in small numbers of patients to increase work performance on a cycle ergometer. ${ }^{520} \mathrm{We}$ used the six-minute walking test as a more appropriate and reproducible test of effort tolerance in patients with chronic bronchitis. All the patients showed improvement in exercise capacity after reduction of packed cell volume.

We showed significant reductions in $T_{L}$ co and $K c 0$, as expected since they are directly related to haemoglobin concentration. ${ }^{21}{ }^{22}$ After correction to a standard haemoglobin concentration the changes in $\mathrm{T}_{\mathrm{L}} \mathrm{CO}$ and $\mathrm{KCO}$ were no longer significant. Small increases in $T_{L}$ co have been found in earlier studies in which packed cell volume was reduced, but no information about smoking habits or carboxyhaemoglobin concentrations was given. ${ }^{1020}$ Cessation of smoking would lead to falls in carboxyhaemoglobin and increases in $T_{L}$ co. Our patients were not smoking at the time of the study and carboxyhaemoglobin concentrations were within the limits for non-smokers.

Our patients showed significant improvements in the tests of mental alertness after erythrapheresis. The lack of improvement in the control subjects suggests that this improvement was not due to learning, but was probably caused by an increase in cerebral perfusion. Although cerebral blood flow is not initially as severely reduced in patients with polycythaemia secondary to hypoxic lung disease as in patients with polycythaemia rubra vera ${ }^{4}$ it does increase after ${ }^{*}$ venesection. ${ }^{3}$ Improvement in mental alertness has been correlated with a rise in cerebral blood flow after venesection in patients with polycythaemia not caused by hypoxic lung disease. ${ }^{17}$

Symptomatic improvement was reported by all our patients, and this was quantified by the significant improvement in the visual analogue scale scores for shortness of breath, sadness, mood, and "feeling terrible." A placebo effect cannot be completely excluded for these subjective results but sham plasmapheresis has been shown not to have such an effect in patients with rheumatoid arthritis. ${ }^{23}$

We estimate the cost for each procedure to be about $£ 80$, including tubing kit, machine depreciation, nursing time, and replacement fluids (these fluids may be more costly if commercial sources are used). This must be set against the costs of multiple visits and the tubing sets used for manual procedures; an average of seven venesections may be required for an equivalent reduction in packed cell volume. There is also an unquantifiable saving in patient time and convenience in undergoing a single controlled procedure with a possible reduction in inpatient care.

We conclude that erythrapheresis is an easy and acceptable procedure that produces significant improvement in symptoms, mental function, and work performance in patients with polycythaemia secondary to chronic hypoxic lung disease.

We thank Dorothy Lord, SRN, for running the cell separator unit, Dr H Wilcox for additional help with the cell separator, and Susan Hall for secretarial help.

Correspondence should be addressed to: Dr D W Empey, London Chest Hospital, Bonner Road, London E2 9JX.

\section{References}

1 Distenfass L, Read J. Pathogenesis of heart-failure in acute-on-chronic respiratory failure. Lancet $1968 ; \mathrm{i}: 570-2$.

${ }^{2}$ Murray JF, Gold P, Johnson BL Jr. The circulatory effects of haematocrit variations in normovolaemic and hypervolaemic dogs. $f$ Clin Invest $1963 ; 42: 1150-9$.

${ }^{3}$ York EL, Jones RL, Menon D, Sproule BJ. Effects of secondary polycythaemia on cerebral blood flow in chronic obstructive pulmonary disease. Am Rev Respir Dis 1980;121:813-8.

4 Wade JPH, Pearson TC, Ross Russell RW, Wetherley-Mein GW. Cerebral blood flow and blood viscosity in patients with polycythaemia secondary to hypoxic lung disease. $\mathrm{Br} M e d \mathcal{F} 1981 ; 283: 689-92$.

${ }^{5}$ Harrison BDW, Davis J, Madgwick RG, Evans M. The effects of therapeutic decrease in packed cell volume on the response to exercise of patients with polycythaemia secondary to lung disease. Clinical Science and Molecular Medicine 1973;45:833-47.

- Segel N, Bishop JM. The circulation in patients with chronic bronchitis and emphysema at rest and during exercise, with special reference to the influence of changes in blood viscosity and blood volume on the pulmonary circulation. $\mathcal{F}$ Clin Invest 1966;45:1555-68.

Dayton LM, McCullough RE, Scheinborn DJ, Weil JV. Symptomatic and pulmonary response to acute phlebotomy in secondary polycythaemia. Chest 1975;68:785-90.

* Constantinidis K. Venesection fatalities in polycythaemia secondary to lung hypoxia. Practitioner 1979;222:89-91.

${ }^{9}$ Gregory RJ. The rapid lowering of haematocrit by exchange transfusion of Rheomacrodex Dextran 40. Acta Med Scand 1971;189:551-4.

in Chamberlain DA, Millard FJC. The treatment of polycythaemia secondary to hypoxic lung disease by continuous oxygen administration. $Q \mathcal{f} \mathrm{Med}$ $1963 ; 32: 341-50$.

"Pengelly CDR. Reduction of excessive haematocrit and red blood cell volume in patients with polycythaemia secondary to hypoxic lung disease by Dapsone and Pyrimethamine. Lancet 1966;ii:1381-6.

12 Jones VJ, Huestis DW, Crotty MJ. Rape and heresy. Plasma Therapy $1980 ; 1: 3$.

${ }^{13}$ England JM, Walford DM, Walters DAW. Reassessment of the reliability of the haematocrit. Br $\mathcal{F}$ Haematol $1972 ; 23: 247-56$. 
14 Dacie JV, Lewis SM. Practical haematology. 5th ed. Edinburgh, London and New York: Churchill Livingstone, 1975:198.

${ }^{15}$ McGavin CR, Gupta SP, McHardy GJR. Twelve-minute walking test for assessing disability in chronic bronchitis. $\mathrm{Br}$ Med 7 1976; :822-3.

${ }^{16}$ Butland RJA, Pang J, Gross ER, Woodcock AA, Geddes DM. Two-, six-, and 12-minute walking tests in respiratory disease. $\mathrm{Br} M e d \mathcal{F} 1982 ; 284$ 1607-8.

17 Willison JR, Thomas DJ, Du Boulay GH, et al. Effect of high haematocrit on alertness. Lancet $1980 ; \mathrm{i}: 846-8$.

${ }^{18}$ Cotes JE, Dabbs JM, Elwood PC, Hall AM, McDonald A, Saunders MJ. Iron deficiency anaemia: its effect on transfer factor for the lung (diffusing capacity) and ventilation and cardiac frequency during submaximal exercise. Clin Sci $1972 ; 42: 325-35$

${ }^{19}$ Clark EH, Wonds RL, Hughes JMB. Effect of blood transfusion on the carbon monoxide transfer factor of the lung in man. Clinical Science and Molecular Medicine 1978;54:627-31.
20 Harrison BDW, Gregory RJ, Clark TJH, Scott GW. Exchange transfusion with Dextran 40 in polycythaemia secondary to hypoxic lung disease. Br Med F 1971 ;iv:713-6.

${ }^{21}$ Roughton FJW, Forster RE. Relative importance of diffusion and chemical reaction rates in determining rate of exchange of gases in the human lung, with special reference to true diffusing capacity of pulmonary membrane and volume of blood in the lung capillaries. $7 \mathrm{Appl} \mathrm{Physiol}$ $1957 ; 11: 290-302$.

${ }^{22}$ Herbert JJ, Weill H, Stuckey WJ, Urner C, Gonzales E, Zisking MM Pulmonary diffusing capacity in polycythaemic states before and after phlebotomy. Diseases of the Chest 1965;48:408-15.

${ }^{23}$ Wallace D, Goldfinger D, Lowe C, et al. A double-blind controlled study of lymphoplasmapheresis versus sham apheresis in rheumatoid arthritis. $N$ Engl f Med 1982;306:1406-10.

\title{
Variation in the use of angiography and carotid endarterectomy by neurologists in the UK-TIA aspirin trial
}

\author{
UK-TIA STUDY GROUP
}

\begin{abstract}
Of 959 patients with complete records at entry to the UK-TIA Aspirin Trial 32\% underwent angiography; for the 27 neurologists with 10 or more patients in the trial this rate varied from $3 \%$ to $100 \%$. Seven per cent of the patients had carotid surgery; similarly the rate varied from $0 \%$ to $25 \%$ depending on the policy of the neurologist. These differences may be partly due to different perceptions of the safety and usefulness of carotid surgery. Ten of $41(24 \%)$ patients undergoing carotid surgery after randomisation had a perioperative stroke, and four of them died.
\end{abstract}

\section{Introduction}

Though carotid endarterectomy is frequently undertaken in patients with transient ischaemic attacks, whether or not it

Members of the study group: Dr A Downie, Dr J Hern (Aberdeen); D J Lyttle, Dr M Swallow (Belfast); Dr M Anderson (Birmingham); Dr M Campbell (Bristol); Dr R Ponsford (Coventry); Dr M Hutchinson, Dr E Martin (Dublin); Dr C Gardner-Thorpe (Exeter); Dr C Hawkes (Ipswich); Dr S Currie, Dr J Howe (Leeds); Dr P Millac, Dr I Pye (Leicester); Dr A Bowden, Dr D Chadwick (Liverpool); Dr M Gross, Dr P Monro (Atkinson Morley Hospital, London); Dr T Fowler (The Brook Hospital, London) Dr R Hughes, Dr S Mossman, Dr M O'Brien (Guy's Hospital, London); Dr C Allen, Dr M Harrison (Middlesex Hospital, London); Dr P Harvey, Dr L A Wilson (Royal Free Hospital, London); Dr D Thomas (St Mary's Hospital, London); Dr G Stern (University College Hospital, London); Dr A Lees (Whittington Hospital, London); Dr D Shepherd, Dr G Yuil (Manchester); Dr D Bates, Dr N Cartlidge, Professor D Shaw, Dr G Venables (Newcastle); Dr J Pilling (Norwich); Dr D Jefferson, Dr A Whiteley (Nottingham); Dr L Blumhardt, Dr C Davis, Dr R Greenhall, Dr N Hyman, Professor B Matthews, Dr C Warlow (Oxford); Dr D Thrush (Plymouth); Dr A Davies-Jones, Dr P Jackson (Sheffield); Dr B Burrell, Dr L Illis, Dr P Kennedy, Dr N Lawton, Dr L McLellan (Southampton); Dr R Weiser (Swansea); Dr J Rees (West Sussex); Trial Office, University Department of Clinical Neurology, Oxford. G Davey, $S$ Haines, $K$ McPherson, J McVittie, D Nassim, P Ogden, J Ratcliff, B Winsley; Clinical Trials Service Unit, Radcliffe Infirmary, Oxford A Daniels, B Hafner, R Peto, S Richards; Clinical Audit Committee B Gribben, M Harrison, C Warlow; Policy Committee Professor P Armitage, University of Oxford, Sir Richard Doll, University of Oxford, Dr R R Russell, National Hospitals for Nervous Diseases, London; External Adviser Professor $\mathbf{M}$ Gent, McMaster University, Hamilton, Canada. improves the long-term outcome beyond what may be expected from medical treatment is debatable. Since 1979 we have been collaborating in the UK-TIA Aspirin Trial, which is a doubleblind and randomised trial of two doses of daily aspirin $(600 \mathrm{mg}$ twice daily and $300 \mathrm{mg}$ daily) compared with placebo in the prevention of stroke and myocardial infarction after transient ischaemic attack. ${ }^{1}$ The individual policies of the participating neurologists on the value of angiography of transient ischaemic attack with a view to vascular surgery (usually carotid endarterectomy but occasionally a by-pass procedure) have varied greatly since the trial protocol neither encourages nor discourages angiography or carotid endarterectomy. Since the study group includes about one-third of all the practising consultant neurologists in the UK we believe that our wide divergences of opinion are worth examining in detail, particularly as our results with carotid surgery have been poorer than most other reported studies.

\section{Patients and methods}

Only the patients who have been randomised in the trial are reported here. The trial is continuing and the treatment allocation to aspirin or placebo is still unknown to the 56 neurologists entering patients from 30 centres. Patients aged 40 years or over with one or more transient ischaemic attacks* or minor stroke* in the three months before randomisation are eligible for the trial. The end-points are major stroke, myocardial infarction, and death; if these occur after the moment of randomisation they are accurately recorded. An entry form gives details of the cerebrovascular episodes, the result of angiography if carried out, and whether carotid endarterectomy was performed before randomisation. Follow-up forms giving end-points, whether

* A transient ischaemic attack is defined by acute focal neurological or ocular symptoms lasting less than 24 hours and thought to be due to vascular disease of an arterial embolic, or thrombotic kind. Minor strokes are defined similarly except neurological symptoms are allowable for up to one week, major strokes lasting for one week or longer. Neurological signs of no functional significance may be found after the resolution of symptoms and include asymmetrical deep tendon reflexes, extensor plantar response, nystagmus, unequal pupils and subjective cutaneous sensory impairment. Such sign probably depend on the period of time between the symptoms and examination, as well as on the skill of the examiner. It is important to stress that at the time of randomisation the patients, even in the minor stroke category, had no symptoms and therefore no disability or handicap. Patients with only non-focal neurological symptoms were not randomised: these include loss of consciousness, faintness, vertigo, imbalance, drop attacks, amnesia, and simultaneous bilateral visual disturbance. 